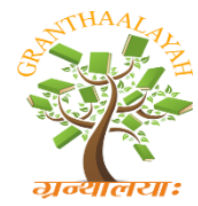

INTERNATIONAL JOURNAL OF RESEARCH GRANTHAALAYAH A knowledge Repository

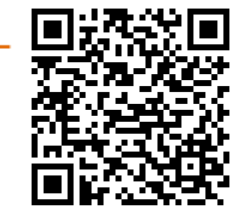

Management

\title{
A STUDY ON THE EFFECTIVENESS OF FLCC PROGRAMME LAUNCHED BY FEDERAL BANK
}

\author{
Sreevidhya $S^{* 1}$ \\ ${ }^{* 1}$ Assistant Professor, Department of Commerce, NSS College, Cherthala, India
}

DOI: https://doi.org/10.29121/granthaalayah.v4.i12SE.2016.2384

\begin{abstract}
The new economic reforms of government, advances in technology and great market orientation and financial innovation have reshaped the financial landscape. It means the people have so many investment opportunities. Poor people particularly in rural areas are often wary of banks and finds branches intimidating. A profound lack of financial literacy also reinforces the sense of alienation. The rural poor are also unaware about how to deal with credit, how to avoid incurring debts that cannot be repaid. In order to solve these problems RBI has decided to provide financial literacy along with credit counselling. As such RBI has come out with a model scheme on FLCC and advised banks to set up as many FLCC in order to achieve at least one FLCC per block.

In consonance with RBI directives the Federal Bank, the first bank in the state which started FLCC, established a trust namely 'Federal Ashwas Trust'. The main objective of this trust is the establishment and running of 'Federal Aswas Financial Literacy Centers' (FAFLC) for providing financial education to the public. The objective of the scheme is to provide free financial literacy education and credit counselling to people in rural and urban area. Through this FLCC centers across the state, customers are educated on responsible borrowing, proactive and early savings and also offers debt counselling to individuals.
\end{abstract}

Keywords: Financial Literacy; Credit Counselling; Debt Management.

Cite This Article: Sreevidhya S. (2016). "A STUDY ON THE EFFECTIVENESS OF FLCC PROGRAMME LAUNCHED BY FEDERAL BANK." International Journal of Research - Granthaalayah, 4(12)SE, 16-22. https://doi.org/10.29121/granthaalayah.v4.i12SE.2016.2384.

\section{Introduction}

"The Perfect banking partner"- Federal Bank. Yes, the Federal Bank has become the perfect banking partner of the common man not only in its banking activities but also in their social commitment through inculcating financial literacy among the people. Federal bank is the first private bank which took initiative in implementing RBI directives on financial literacy. Till now 
banks in all started FLCCs in all blocks (738) of India with 152 FLCCs in Kerala and 12 in Alappuzha.

The objective of the scheme is to provide free financial literacy education and credit counselling to people in rural and urban area. Financial literacy aims to empower the people to make informed decisions and to aware them to know where to go for help and how to take effective actions to improve their financial well-being etc. Credit Counselling aims to explore the possibility of repaying debts outside bankruptcy and educate the debtor about the credit budgeting and financial management.

\section{Objectives of FLCC}

1) To educate the people in rural and urban areas with regard to various financial products and services available from the formal financial sector.

2) To make the people aware of the advantages of being connected with the formal financial sector

3) 3.To provide a face to face counselling services including education on responsible borrowing and offering debt counselling to individuals who are indebted to formal and informal financial sectors.

4) To reconstruct the debt restructuring plans for borrowers in distress and recommend the same to formal institutions.

Through FLCC the bank is providing education to the people about how to avoid incurring debts that cannot be repaid, how to manage their existing debt, general information about the banking services- different accounts, interest rates, different types of loans, their formalities, time norms for banking transactions, debt management plan, credit counselling etc. The classes are conducted by the experienced persons appointed by the federal bank

As on June 2013 there are19 FLCC centers of Federal Bank are functioning 14 districts of Kerala. Among them three FLCCs are located in Alappuzha District. Alappuzha district is the district with highest number of FLCCS of Federal Bank. Therefore Alappuzha District is selected for the purpose of study.

Details of FLCC centres in Alappuzha district

\begin{tabular}{|l|l|l|l|}
\hline Sl.No. & \multicolumn{1}{|c|}{ Location } & \multicolumn{1}{|c|}{ FLCC } & No.of beneficiaries \\
\hline 1. & Mararikukalam & $\begin{array}{l}\text { Federal Ashwas FLCC, Gandhi } \\
\text { SmarakaGramaSevaKendram, S.L. } \\
\text { Puram P.O., Alappuzha - 688 523 }\end{array}$ & 668 \\
\hline 2. & Alappuzha & $\begin{array}{l}\text { Federal Ashwas FLCC, Gandhi } \\
\text { SmarakaGramaSevaKendram Sub center, } \\
\text { Moosariparampil, District Court Road, } \\
\text { Thathampally P O, Alappuzha -688001 }\end{array}$ & 212 \\
\hline 3. & Kuttanad & $\begin{array}{l}\text { Federal Ashwas FLCC, Gandhi } \\
\text { SmarakaGramaSevaKendram, Kuttanad } \\
\text { Sub- Centre, Vezhapra, Ramankary P.O., } \\
\text { Alappuzha }\end{array}$ & 624 \\
\hline
\end{tabular}


As far as the FLCC center in Alappuzha district is concerned there are 3 FLCC centers functioning with Mararikulam FLCC as the main center. The programme is running through GSGSK, an NGO functioning for the betterment of rural poor. From its very beginning this center is very effective and responsible in discharging its ultimate aim. Classes are conducted on continuous basis among the different groups of people according to their requirements. The beneficiaries include farmers, youngsters, kudumbasree members, SHG members, school college students etc. The bank has been conducting various financial literacy classes for higher secondary students to educate them on banking and various financial services; so far 15,000 students have benefitted from this programme, the officials said. The majority of the people in this area are now aware of the financial matters, responsible borrowing, debt management etc. Through these FLCC the beneficiaries gets the following information.

- Banks-Its functions, activities

- Importance of a bank customer

- Various banking services to the customers

- General information on banking transactions

- Various exchange facilities

- Time norms for banking transactions

- Various types of deposits-terms\&conditions, its renewal, premature withdrawal, application of interest rates etc.

- Loan accounts- Interest rates applicable, overdue in loan accounts, premacture closure of loan account etc.

- Security features of bank notes.

\section{Significance and Scope of the Study}

The innovative banking products, aggressive market orientation and consumerisation have forced the vulnerable sections of people to avail debt to finance their consumption needs. Sometimes it leads to over indebtedness and the rural poor are also unaware about how to deal with credit, how to avoid incurring debts that cannot be repaid.

RBI has introduced FLCC programme as a model scheme for solving this situation. A study on the effectiveness of this programme will help to know whether it has succeeded in bringing a financial discipline among the masses.

The present study titled "Effectiveness of FLCC programme launched by Federal Bank in Alappuzha district" is limited to programme conducted by Mararikulam FLCC. The beneficiaries of Mararikulam FLCC are selected for the study.

\section{Objectives}

1) To analyse the modus-operandi of the FLCC programme of Federal Bank Ltd.

2) To investigate in to the effectiveness of the FLCC programmes among the beneficiaries. 


\section{Methodology}

The study is based on both primary and secondary data. For the purpose of the study FLCC in Mararikulam is selected as sample. The reason for selecting the sample is nothing but the highest number of beneficiaries. Among the 668 beneficiaries 40 beneficiaries are selected at random to elicit the required information. Primary data is collected from the officials and beneficiaries through direct interview and questionnaire method. Secondary data is collected from various publications of banks and other research publications in the form of the Journals, reports etc . All the data mined are processed in terms of objectives of this study to arrive at conclusions.

\section{Analysis and Interpretations}

The data collected for this study is analysed on the basis of three parameters. Under each of these, various sub parameters are analysed.

I. I. Level of general awareness about banking functions and activities

II. Customer oriented information

III. Other information

\section{Level of general awareness about banking functions and activities}

In this section respondent's general awareness are analysed on the basis of their awareness level on the following areas

a. Bank \& its functions

b. Banking hours

c. Banking services

d. Banking hours

Table 1.1: Customer oriented information - Deposits

\begin{tabular}{|c|c|c|c|c|c|c|c|}
\hline \multirow{2}{*}{$\overbrace{\text { Areas }}$ Level } & \multicolumn{2}{|c|}{ Below Average } & \multicolumn{2}{|c|}{ Average } & \multicolumn{2}{|c|}{ Above Average } & \multirow[b]{2}{*}{ Total } \\
\hline & $\%$ & No. & $\%$ & No. & $\%$ & No. & \\
\hline $\begin{array}{l}\text { Bank \& its } \\
\text { functions }\end{array}$ & 15 & 6 & 30 & 12 & 55 & 22 & 40 \\
\hline Banking hours & 13 & 5 & 25 & 10 & 62 & 25 & 40 \\
\hline Banking services & 2 & 1 & 25 & 10 & 73 & 29 & 40 \\
\hline $\begin{array}{l}\text { Banking } \\
\text { transactions }\end{array}$ & 10 & 4 & 20 & 8 & 70 & 28 & 40 \\
\hline
\end{tabular}

The above discussion reveals that the awareness about banking functions, banking hours etc are known to more than half of the respondents. Whereas majority of them are of the opinion that they know about the banking services and transactions. 


\section{Customer oriented details}

In this section respondents' awareness about those information which are specific to a customer are analysed in details through two heads

1) Deposits of respondents

2) Loans of respondents

1) Deposits

Under this head respondents awareness about their deposit account are analysed on the basis of following.

a. Awareness about types of deposit

b. Awareness about terms and conditions applicable to their deposit

c. Awareness about minimum balance

d. Awareness about application of interest on the deposit

Table 1.2: Customer oriented information - Deposits

\begin{tabular}{|l|l|l|l|l|l|l|l|}
\hline \multirow{2}{*}{ Areas } & \multicolumn{2}{|l|}{ Below Average } & \multicolumn{2}{l|}{ Average } & \multicolumn{2}{l|}{ Above Average } & \multirow{2}{*}{ Total } \\
\cline { 2 - 8 } & $\mathbf{\%}$ & No. & $\%$ & No. & \% & No. & \multirow{2}{*}{ \% } \\
\cline { 2 - 7 } Type of deposit & 20 & 8 & 50 & 20 & 30 & 12 & 40 \\
\hline $\begin{array}{l}\text { Terms \& } \\
\text { conditions }\end{array}$ & 30 & 12 & 55 & 22 & 15 & 6 & 40 \\
\hline Minimum balance & 5 & 2 & 33 & 13 & 62 & 25 & 40 \\
\hline $\begin{array}{l}\text { Application of } \\
\text { interest }\end{array}$ & 23 & 9 & 32 & 13 & 45 & 18 & 40 \\
\hline
\end{tabular}

The above table regarding the respondent's awareness regarding their deposits shows that more than half percentage of the respondents are have awareness about their type of deposit and its terms and conditions. A sizeable number of respondents are aware about the minimum balance required for their deposit and interest rate applicable on it.

Table 1.3: Customer oriented information - Loans

\begin{tabular}{|c|c|c|c|c|c|c|c|}
\hline \multirow{2}{*}{ Areas $\quad$ Level } & \multicolumn{2}{|c|}{ Below Average } & \multicolumn{2}{|c|}{ Average } & \multicolumn{2}{|c|}{ Above Average } & \multirow[b]{2}{*}{ Total } \\
\hline & $\%$ & No. & $\%$ & No. & $\%$ & No. & \\
\hline Type of loan & 8 & 3 & 27 & 11 & 65 & 26 & 40 \\
\hline $\begin{array}{l}\text { Terms \& } \\
\text { conditions }\end{array}$ & 5 & 2 & 25 & 10 & 70 & 28 & 40 \\
\hline Repayment period & 7 & 3 & 20 & 8 & 73 & 29 & 40 \\
\hline $\begin{array}{l}\text { Application of } \\
\text { interest rate }\end{array}$ & 10 & 4 & 13 & 5 & 77 & 31 & 40 \\
\hline
\end{tabular}


Premature closure of loan account

\begin{tabular}{|l|l|l|l|}
\hline 25 & 10 & 33 & 13 \\
\hline
\end{tabular}

One who look at the above table can easily understand that a sizeable number of respondents have average or above average awareness about different aspect of their loans.

\section{Other information}

This section covers other information which is not covered under general information and customer oriented information. Respondents awareness are analysed on the basis of following attributes.

a. Time norms for different banking transactions

b. Exchange of soiled or toned notes with the bank

c. Security features of bank notes

d. Locker facilities available in bank

e. Usage of ATM counters

Table 1.4: Other information

\begin{tabular}{|l|l|l|l|l|l|l|l|}
\hline \multirow{2}{*}{ Areas } & \multicolumn{2}{|l|}{ Belowel Average } & \multicolumn{2}{l|}{ Average } & \multicolumn{2}{l|}{ Above Average } & \multirow{2}{*}{ Total } \\
\cline { 2 - 8 } & $\mathbf{\%}$ & No. & $\%$ & No. & $\%$ & No. & \% \\
\hline Time norms & 20 & 8 & 30 & 12 & 50 & 20 & 40 \\
\hline Exchange facilities & 0 & 0 & 12 & 5 & 88 & 35 & 40 \\
\hline Security features & 7 & 3 & 45 & 18 & 48 & 19 & 40 \\
\hline Locker facilities & 0 & 0 & 18 & 7 & 82 & 33 & 40 \\
\hline Usage of ATM & 12 & 5 & 23 & 9 & 65 & 26 & 40 \\
\hline
\end{tabular}

The above table highlights that only a half of the respondents have complete awareness about time norms in banking transactions. Almost all the respondents are aware about the exchange of toned/ soiled notes with the banks and usage of ATMs. There are no respondents who are not aware about the locker facilities provided by the banks.

\section{Findings}

1) The majority of the respondents are aware about the responsible borrowing, debt management etc.

2) After becoming a beneficiary of the scheme peoples have financial literacy and most of them are aware about:

a. General information about the bank

b. Customer oriented information

c. Other information-time norms, security features of notes, locker facilities etc.

3) Customers are decided to decrease the dependence on informal sources of funds.

4) They are decided to settle down the debts taken for unproductive purposes. 


\section{Conclusion}

The FLCC programme launched by the Federal Bank Ltd, as per the directives of the RBI, has attained a remarkable heights in providing financial literacy among the different targeted groups. The bank is proved as the 'the perfect banking partner' of the people by providing awareness about the financial information required by a common man. The programme has a considerable role in bringing a positive attitude towards debt management, financial planning, responsible borrowing etc. and making them able to take informed judgements and responsible decisions regarding the use and management of money.

\section{References}

[1] Anand, S. C. (1990). Rural Banking and Development. Delhi: UDH Publishing House.

[2] Golden.S, A. R. (2015). Regional Imbalance affecting quality of e-banking services with special reference to Tuticorin District- An Analysis. International Journal of Research, 2(3), 788-799.

[3] Kothari, C. R. (1990). Research Methodology - Methods and Techniques (Second Edition). New Delhi: Wiley Eastern Limited

[4] Pandey, M.C. and Kumar, S. (2005): Banking Trends \& Practice, Anamika Publications and Distributions, LTD, New Delhi

[5] Regi, S. B., \& Golden, S. A. R. (2014). Attitude of Rural People Towards Technology Inclusion In Banking Services At Tirunelveli District. IGJAE - Indo Global Journal Of Applied Management Science, 2(2).

[6] Regi, S. B., \& Golden, S. A. R. (2014). Customer Preference Towards E- Channels Provided By State Of Bank Of India.

[7] Regi, S. B., \& Golden, S. A. R. (2014). Customer Preference Towards Innovative Banking Practices Available In State Bank Of India At Palayamkottai. Sankhya International Journal Of Management And Technology, 3(11 (A)), 31-33.

[8] Regi, S. B., Golden, S. A. R., \& Franco, C. E. (2014). A STUDY ON IMPACT OF INFORMATION TECHNOLOGY (IT) IN MODERN BANKING SECTOR. Golden Research Thoughts, 3(9), 1-4.

[9] Regi, S. B., Golden, S. A. R., \& Franco, C. E. (2014). ROLE OF COMMERCIAL BANK IN THE GROWTH OF MICRO AND SMALL ENTERPRISES. Golden Research Thoughts, 3(7), $1-5$.

[10] Regi, S. B. CREDIT CARD-A WAY TO GENERATE LEGITIMATE MONEY FOR PAYMENTS.

[11] www.federalbank.co.in. 